\title{
MARIONETKI, MASKI I SNY. WOKÓŁ ROMANTYCZNEJ NICOŚCI
}

\author{
MAGDALENA SIWIEC*
}

Pojęcie nicości w badaniach nad literaturą pierwszej połowy XIX wieku wiąże się z takimi zjawiskami jak romantyzm negatywny, czarny romantyzm, melancholia, a także nihilizm. Nie są to pojęcia synonimiczne, choć często bywają odnoszone do jednego dzieła. Ponadto są one zmienne historycznie - szczególnie jeśli chodzi o kategorię nihilizmu. Chcę przyjrzeć się wczesnoromantycznym tekstom uznawanym za nihilistyczne, w innym niż współczesny, ponietzscheański, sensie; tekstom, które można nazwać „nicościowymi”, bo niewątpliwie to nicość w nich - jakkolwiek paradoksalnie to brzmi - uobecniona może stanowić klucz do ich interpretacji.

Samo pojęcie nihilizmu jest we współczesnych badaniach literaturoznawczych odnoszone do rozmaitych zjawisk, zarówno zgodnie z historycznym rozumieniem pojęcia, jak i w sposób anachroniczny. Z lektury prac o charakterze interpretacyjnym poświęconych tekstom okresu romantyzmu ${ }^{1}$ można wywnioskować, że nihilizm bywa rozumiany jako:

1. dziewiętnastowieczna kategoria filozoficzna utożsamiana z idealizmem transcendentalnym (związana ze sceptycyzmem, spinozjańskim panteizmem i sporem o ateizm);

2. narcyzm, zamknięcie w pułapce zabsolutyzowanej jaźni;

3. zbytnie uprzywilejowanie rozumu;

4. rozchwianie poznawcze;

5. zawieszenie, krytyka lub przewartościowanie wartości;

6. kwestionowanie prawd uniwersalnych, podważanie mitów;

* Magdalena Siwiec - dr hab., Wydział Polonistyki UJ.

1 Wyprowadzam te wnioski na podstawie lektury z prac zawartych w tomie Nihilizm i historia. Studia z literatury XIX i XX wieku, red. M. Sokołowski i J. Ławski, Białystok-Warszawa 2009: M. S ok ołow sk i, Wstęp; K. S aw i ck a, Fragment poza „Wielkq Całościq” - o nihilizmie I cześci „Dziadów” Adama Mickiewicza; M. Kuziak, Stowacki-nihilistyczny? Wokót „Kordiana”; J. Ław ski, Nicościq podszyty Słowacki (Juliusz); H. Krukowska, Nocne uniwersum w myśli romantycznej Zygmunta Krasińskiego; J. Fiećk o, Ateizm, rewolucja, Rosja. Trzy wcielenia nihilizmu według Zygmunta Krasińskiego; A. S ekuła, Twierdza podmywana falami morza. Wątki nihilistyczne historiozofii Zygmunta Krasińskiego; M. S a g a i ak, Rozpacz i walka z nihilizmem. „Fantazja konania” Zygmunta Krasińskiego. 
7. negacja czy anihilacja Boga;

8. poczucie utraty sensu w historii, pozbawienie sensotwórczej funkcji cza$\mathrm{su}$;

9. rewolucyjne burzenie porządku społecznego, anarchistyczny bunt przeciw władzy;

10. unieważnienie zewnętrznej rzeczywistości i nadanie prymatu nad nią literaturze, absolutyzacja sztuki;

11. konfrontacja bohatera z nicością, skrajny pesymizm wynikający z zagrożenia wewnętrznym poczuciem nicości, za którego znaki zewnętrzne uznawane są lęk i melancholia;

12. ufundowanie życia na negacji.

Z tego katalogu wskazującego na wieloznaczność pojęcia - rozumianego w kategoriach ontologicznych, epistemologicznych bądź etycznych - wynika przede wszystkim to, że interpretacja tekstów romantycznych w kontekście nihilizmu wymaga doprecyzowania, jaki aspekt zjawiska znajdzie się w centrum zainteresowania.

W dyskusji nad literackim nihilizmem romantycznym przywołuje się nazwiska Augusta Klingemanna, Jean Paula Richtera, Georga Büchnera, Heinricha von Kleista - śmiertelnej ofiary „kryzysu kantowskiego”, Ludwiga Tiecka - twórcy Ludwika Lovella, pierwszego bohatera-nihilisty, Friedricha Hölderlina, Karela Hynka Máchy; w Polsce także Antoniego Malczewskiego, Adama Mickiewicza, Juliusza Słowackiego, Zygmunta Krasińskiego² ${ }^{2}$. Niewątpliwie archetekstem dla literatury nihilistycznej są Straże nocne Bonawentury, czyli Klingemanna. Ważne miejsce zajmuje tu również, stanowiący fragment powieści Siebenkäs, tekst Jean Paula, skądinąd zajadłego przeciwnika nihilizmu, zatytułowany Mowa umarłego Chrystusa wygłoszona ze szczytu kosmicznego gmachu o tym, że nie ma Boga. Tekst ten - z uwagi na nieznaczną zmianę w tłumaczeniu na język francuski Mme de Staël - zyskał wymowę sprzeczną z intencjami autorskimi jako pierwszy tekst o śmierci Boga ${ }^{3}$. Poza tymi literackimi świadectwami nihilistycznej pokusy interesować mnie będą drobne utwory Hölderlina, Büchnera i Kleista oraz dwa poematy: Maj Máchy i Maria Malczewskiego - najważniejszy polski tekst „,nicościowy". Są to utwory bardzo od siebie odległe pod względem gatunkowym, kompozycyjnym, językowym. Na czym polega ich wspólnota? Co pozwala na lekturę tych tekstów w kontekście nihilistycznym?

${ }^{2}$ Zob. np.: M. A. Gille spie, Nihilism before Nietzsche, Chicago 1996; J. Wasiew ic z, Oblicza nicości. Z dziejów nihilizmu europejskiego w XIX wieku, Wrocław 2010; M. Ż mi g rod zka, Rozdrożny i gra z nicościq [w:] B on a w entura [A. E. F. Kling e man n], Straże nocne, przeł. K. Krzemieniowa i M. Żmigrodzka, Białystok 2006; W. S z tu r c, Mitologia nicości: Antoni Malczewski [w:] O obrotach sfer romantycznych: studia o ideach i wyobraźni, Bydgoszcz 1997; przywołane wyżej prace z tomu Nihilizm i historia..., op. cit.

${ }_{3}$ Zob. M. J an ion, M. Ż mi grodzka, Romantyzm i egzystencja. Fragmenty niedokończonego dzieła, Gdańsk 2004, rozdz. „Apokalipsa bez zbawienia. Tematy jeanpaulowskie”, s. 132-143. 
By odpowiedzieć na to pytanie, trzeba przywołać romantyczne rozumienie nihilizmu. Jego kariera w sensie filozoficznym i literackim rozpoczyna się pod koniec wieku XVIII w Niemczech, choć można wskazywać na jeszcze wcześniejsze antecedencje tego pojęcia i związanej z nim postawy ${ }^{4}$. Warto podkreślić, że pojęcie nihilizmu pojawiło się od razu w znaczeniu negatywnym - jako zarzut, a nawet obelga - i tak w dużej mierze funkcjonowało w okresie romantyzmu. Zasadniczo zostało sformułowane przez swoich przeciwników, nie zdeklarowanych zwolenników, których - do Jedynego Maxa Stirnera (a więc do roku 1844) i Ojców i dzieci Iwana Turgieniewa (1862) - trudno byłoby jednoznacznie wskazać (może poza Ludwikiem Lovellem Tiecka). Nie bez znaczenia dla literatury dziewiętnastowiecznej było także funkcjonujące we Francji porewolucyjnej pojęcie nihiliste albo rienniste określające osobę nie interesującą się niczym i w nic nie wierzącą, także egoistę ${ }^{5}$ Również w tym wypadku miało ono wymiar negatywny. W sensie pozytywnym odrzucenie wartości, zwłaszcza związanych z religiami, postulował, między innymi, Anacharsis Cloots, piewca ateizmu republikańskiego ${ }^{6}$. Swoich ideałów ten baron pruski, który, zafascynowany francuskimi encyklopedystami, przyłączył się do sankiulotów (skazany zresztą, jak wiele dzieci rewolucji, na gilotynę), bronił następująco: „La république des droits de l'homme, à proprement parler, n'est ni téiste ni athée; elle est nihiliste"7. Idealna republika to dla niego zatem republika nihilistyczna, wymagająca zniesienia wszelkich kultów (la nullité des cultes).

Za wprowadzenie pojęcia nihilizmu do dyskusji filozoficznej odpowiedzialny jest Friedrich Heinrich Jacobi, nawet jeśli dużą rolę odegrali jego poprzednicy - Baruch Spinoza, George Berkeley, Immanuel Kant, Johann Gottlieb Fichte i Friedrich Wilhelm Joseph von Schelling - których tezy na swój sposób zinterpretował i tym samym związał nihilizm ze sporem o ateizm i z krytyką idealizmu transcendentalnego ${ }^{8}$. W słynnym liście otwartym do Fichtego z 1799

${ }^{4}$ O początkach nihilizmu zob. M. A. Gilles pie, op. cit.; J. P. Faye i M. Coh en-Halimi, L'historie caché de nihilisme. Jacobi, Dostö̈evski, Heidegger, Nietzsche, Paris 2008, rozdz. I i II; W. Mülle r-La u te r, W. Goerdt, Nihilizm, przeł. S. Gromadzki [w:] Nihilizm. Dzieje, recepcja, prognozy, wybór i oprac. S. Gromadzki, J. Niecikowski, Warszawa 2001; O. Pog geler, Hegel i początki dyskusji o nihilizmie, przeł. S. Gromadzki [w:] ibidem; W. Mülle r-La u te r, Nihilizm jako konsekwencja idealizmu. F. H. Jacobiego krytyka filozofii transcendentalnej i jej następstwa historyczno-filozoficzne, przeł. S. Gromadzki [w:] ibidem; J. Wa s i e w i cz, op. cit., rozdz. I.

${ }^{5} \mathrm{O}$ niezależnym, równoległym funkcjonowaniu określenia nihilizm we Francji porewolucyjnej i rozwoju filozoficznego pojęcia nihilizmu w Niemczech zob. W. Müller-Lauter, W. Goerdt, op. cit., s. 7.

${ }^{6}$ Zob. J. P. Faye i M. Cohen-Halimi, op. cit., rozdz. I.

${ }^{7}$ „Republika praw człowieka nie jest, w sensie ścisłym, ani teistyczna, ani ateistyczna; jest nihilistyczna”. Cyt. [za:] ibidem, s. 21, przekł. - M. S.

${ }^{8}$ M. Wer n e r pisze: „Nihilizm stał się rewersem idealizmu, jego »ciemną stroną« i prawdopodobną konsekwencją”; M. Wern er, Atheismusstreit, „Kronos” 2011, nr 1, s. 7. Na temat roli Jacobiego i Fichtego, Kanta i Hegla w sporze o nihilizm zob. też: H. Ko hl en be rg e r, Nihilizm woświeceniu, przeł. S. Bafia, „Alma Mater” 2004, nr 62; W. Mü1le r-La u ter, op. cit., oraz P. De h nel, 
roku nihilizmem nazwał on filozofię idealistyczną, której zarzucił pogrążanie się w abstrakcyjnych spekulacjach podważających wszelką pewność, de facto - podważających istnienie rzeczywistości, także realność Boga9 ${ }^{9}$ Jak materializm jest dla Jacobiego próbą objaśnienia wszystkiego za pomocą samookreślającej się materii, tak idealizm - za pomocą samookreślającej się inteligencji. Ten ostatni - szczególnie w wydaniu Fichtego - prowadzi zdaniem Jacobiego do uznania Ja za centrum i przyjęcia wyłącznie subiektywnej perspektywy. Refleksja to niszczenie i stwarzanie jednocześnie. Jest bowiem możliwa tylko przez abstrakcję, dzięki której wyobraźnia przetwarza rzecz w subiektywne pojęcie, czyli zamienia w nicość. Każda rzecz poznawana przez Ja musi zostać jako rzecz obiektywna zniszczona, przesunięta w sferę ,produktywnej wyobraźni”. Realne pozostaje tylko Ja, a poznanie przekształca się w unicestwianie. Jacobi pisze pod wpływem Fichteańskiej filozofii: „,...] jawiło mi się, iż wszystko było nicością, z wyjątkiem mojej - tylko w pewien sposób ograniczonej - swobodnej wyobraźni"10. W ten sposób człowiek staje się stwórcą świata i siebie samego, a także Boga, z którego czyni pojęcie, a więc uzależnia go od siebie i sam stawia się na jego miejscu.

Ustanowienie przez idealistów Ja w centrum i wielka rola przypisywana wyobraźni musiała być kusząca dla romantycznych indywidualistów. Ta perspektywa jest jednak zarówno dla Jacobiego, jak i dla pisarzy romantycznych, trudna do przyjęcia. Jacobi odrzuca nicość i zakłada istnienie Boga jako żywej istoty, proponuje szukanie prawdziwości, która leży poza wiedzą ${ }^{11}$. Jeśli bowiem człowiek chce uzasadnić siebie tylko w sobie samym, uczynić się Bogiem, wszystko mu się rozpada w jego własnej nicości. Tak argumentując, Jacobi przenosi dyskusję na kwestie moralności. Wyzwolenie od Boga jest dla niego tożsame z wytworzeniem pustki, a nicość to pozorność, widmowość, zjawiskowość bytu ${ }^{12}$.

Antynomie rozumu. Z dziejów filozofii niemieckiej XVIII i XIX wieku, Wrocław 1998. O stosunku Jacobiego do Fichtego w kontekście nihilizmu zob. też J. P iór c zy ń s ki, Pierwszy egzystencjalista. Filozofia absolutnej skończoności Fryderyka Jacobiego, Wrocław 2006, s. 34-42.

9 Jacobi podejmował te problemy również w swoich tekstach literackich. Piszą o nich: J. P. Faye i M. Cohen-Halimi, op. cit., rozdz. II; O. Pog gele r, op. cit., s. 30-33.

${ }^{10}$ F. H. J a cobi, List o nihilizmie, przeł. S. Gromadzki, „Przegląd Filozoficzno-Literacki” 2004, nr 1, s. 50. J. Wasiewicz o użyciu pojęcia nihilizm przez Jacobiego pisze: „Jacobi ma tu na myśli konsekwentny idealizm, tj. taki, który całą rzeczywistość ujmuje jako wytwór absolutnego czy też transcendentalnego Ja"; op. cit., s. 32.

${ }^{11} \mathrm{~W}$ przeciwieństwie do Fichtego, według którego myślenie o Bogu jako osobnej istocie, źródle moralnym jest nakładaniem na Boga ludzkich ograniczeń, powielaniem samego siebie w obrazie Boga. Boskość to dla niego moralny porządek, który odczuwamy jako naszą powinność. Zob. J. G. Fic hte, O podstawie naszej wiary w boski porzqdek świata, przeł. M. Rutkowska, „Kronos” 2011, nr 1, s. 15. Z kolei w otwartym liście, broniąc się przed zarzutem ateizmu, Fichte dowodzi, że pojęcie Boga jako szczególnej substancji jest niemożliwe, Boga nie da się wyprowadzić ze świata zmysłowego, zob. J. G. F i c h te, Odwołanie do opinii publicznej, przeł. E. Rzanna, s. 39, „Kronos” 2011, nr 1. Posługując się pojęciami stosowanymi przez Jacobiego, korzystam z cytowanego wyżej przekładu listu do Fichtego.

${ }^{12} \mathrm{Na}$ ten temat zob. J. Wasiewicz, op. cit., rodz. I, zwł. s. 49; J. P. Faye i M. Cohen-Hali mi, op. cit., s. 44-45. 
Nałożenie na siebie rozmaitych znaczeń nihilizmu: idealizmu, ateizmu, indyferentyzmu i związanie z hasłami rewolucyjnymi, spowodowało połączenie - czy raczej pomieszanie - w tym jednym określeniu zagadnień filozoficznych i politycznych. Dla przykładu - dla Krasińskiego nihilizm mógł oznaczać w równym stopniu filozofię niemiecką, rewolucję i carski despotyzm - wszystkie trzy równie złe i niebezpieczne ${ }^{13}$. Źródeł widocznej w przywołanych wcześniej koncepcjach badaczy romantyzmu wieloznaczności pojęcia należy zatem upatrywać jeszcze w wieku XVIII, choć duży wpływ na nią miała oczywiście późniejsza „kariera” nihilizmu. Rację ma współczesny teoretyk literatury, pisząc, że w przypadku wielu tekstów literackich, należałoby mówić raczej o czymś w rodzaju „,nihilistycznej wrażliwości"14.

Negatywny wydźwięk opisywanego tu pojęcia wiązał się z pewną nim fascynacją. Ważne wydaje się, że dla przeciwników nihilizmu walka z nim jest walką z widmem, które - jak widać choćby w cytowanym liście Jacobiego - ich samych przeraża, odzwierciedla ich najsilniejsze lęki, które zostają zapisane w ich tekstach. Sam Jacobi opisywał doświadczenie nieskończonego trwania, utożsamiając je z myślą o unicestwieniu jako doświadczenie rozpaczliwe, nie do zniesienia, odstręczające ${ }^{15}$. W tekstach Jacobiego, Jean Paula, Bonawentury, Hölderlina, Kleista, nihilizm wiąże się z doświadczeniem nicości, ze swoistym tremendum, właśnie dlatego, że jest czymś, co budzi sprzeciw. Sam fakt, że owa nicość - jako konsekwencja idealizmu czy też wyraz agnostycyzmu - jest do pomyślenia, rodzi rozpacz i trwogę, przed którą trzeba się bronić, ale ona - niejako tylnymi drzwiami - wraca. Staje się pokusą. To ona leży u źródeł krytyki Fichtego dokonanej przez Jacobiego. Można powiedzieć, że romantycy są skażeni nicością, że są uwikłani w nihilizm, nawet jeśli go odrzucają i decydują się na jedyny przed nim ratunek, który postulował już Jacobi, a który Søren Kierkegaard nazwał skokiem w wiarę. Trudno zatem wskazać na romantyczną twórczość jednoznacznie pronihilistyczną. Można za to mówić zarówno o filozofii, jak i - zwłaszcza - o literaturze tego okresu jako nihilizmem „skażonej”, zafascynowanej, ku niemu - czasem wyraźnie wbrew deklarowanemu przez autorów konstruktywnemu myśleniu - zmierzającej. Niewątpliwie odnaleźć można wątki nihilistyczne u pisarzy jawnie i manifestacyjnie nihilizm potępiających, pisarzy konserwatywnych, jak Richter czy Krasiński ${ }^{16}$.

${ }^{13}$ Zob. J. Fiećk o, op. cit.

${ }_{14}$ M. Januszkiewicz, Horyzonty nihilizmu. Gombrowicz, Borowski, Różewicz, Poznań 2009, s. 67.

${ }^{15}$ Zob. W. Müller-Lauter, op. cit., s. 73. O tym epizodzie Jacobiego pisze Wasiewicz, porównując go do szwajcarskiego doświadczenia Nietzschego, zob. W. Müll er-L a u te r, op. cit., s. 35-36; P. Dehnel, op. cit., s. 119.

16 Zob. M. Janion, M. Żmigrodzka, op. cit., s. 134-138; A. Sekuła, op. cit. i M. Sag a i ak, op. cit. Badaczki piszą, że nihilizm jest podziemnym nurtem twórczości Krasińskiego, istotnym jako kontrapunkt, negatywny punkt odniesienia, dla bohatera stanowi zagrożenie historyczno-społeczne i wewnętrzne. 
Wspomniane tu kwestie filozoficzne znalazły swoje odzwierciedlenie w tematyce tekstów literackich, ale także w ich poetyce, w sposobie konstrukcji świata przedstawionego. Jeśli sam nihilizm jest pojęciem płynnym, na ile można odwoływać się do nihilizmu literackiego? Czy wskazywane ostatnio wyznaczniki literackiego nihilizmu, takie jak: odrzucenie powszechnie obowiązujących wartości, kreacja antybohatera, szczególny typ narracji (prowadzonej z ograniczonej perspektywy), wątek śmierci Boga, podawanie w wątpliwość metafizyki uzasadniającej bycie w świecie - odnoszą się także do romantyzmu $?^{17} \mathrm{Z}$ pewnością po części tak, jednak, jak sądzę, dla przejrzystości wywodu należałoby wrócić do początków i pamiętać o przywołanym tu przed chwilą filozoficznym znaczeniu wczesnego nihilizmu. Wszystkie wymienione tu zjawiska literackie są w romantyzmie pochodną związanego wyobcowaniem Ja zachwiania ontologicznego statusu rzeczywistości.

Dowodu na romantyczny nihilizm literacki, należy szukać w samym romantyzmie, nie poza nim. A zatem można mówić o romantycznej literaturze nihilistycznej, bo czynili to sami romantycy. Jak Jacobi krytykuje Fichtego, tak wtórujący mu i świadomie do jego tez nawiązujący Jean Paul piętnuje ,nihilistów poetyckich" (tego określenia używa), do których zalicza Schlegla i Novalisa. Pisze: „Nasze czasy przeniknięte są duchem anarchicznej samowoli, która w porywie egotyzmu gotowa jest zniszczyć cały świat - czy nawet wszechświat - żeby z nicości uczynić sobie wolną przestrzeń dla własnych g i e r" ${ }^{\prime \prime}$. Za nihilistyczne w sensie romantycznym uznać należałoby zatem takie utwory, w których świat przedstawiony staje się światem zawieszonym w nicości, pozbawionym odniesienia poza podmiotem - czy to w rzeczywistości zewnętrznej, czy w absolucie - w Bogu. To świat, jaki wyczytuje z dzieła Fichtego Jacobi. Taki świat rozpadający się, zmierzający ku nicości, pozbawiony referencjalności-jest wspólnym elementem różnych gatunkowo tekstów nazwanych przeze mnie „nicościowymi”, wymienionych na początku tego artykułu. Pojawia się on w literaturze epoki zasadniczo w formie hipotezy. Myśl o nicości, zarazem przyciągająca i odstręczająca, zostaje wyartykułowana, ale w sposób niejako zamortyzowany, nie pozwalający przekroczyć granicy, poza którą jest ostateczność - Kleistowska lub Hölderlinowska. Niepewny status ontologiczny świata przedstawionego podkreślają rozmaite zabiegi dekompozycyjne - sobowtórowość, wielowariantowość, fragmentaryczność fabuły, zaburzenie jej chronologii. W każdym z przywołanych tu utworów - odmienne. „Buforem bezpieczeństwa” staje się w tych tekstach wpisanie doświadczenia nicości w ramę snu lub wizji szaleństwa, a także odsłanianie iluzoryczności, literackości świata przedstawionego, jego teatral-

${ }_{17}$ M. Januszkiewicz, op. cit., s. 70-71.

18 J e an Paul, Estetyka. Kurs przygotowawczy, przeł. P. Graczyk, „Kronos”, s. 62. O Estetyce Jean Paula, w której ,poetyckim nihilistom” pisarz zarzuca arbitralny egotyzm, skrajny subiektywizm, oderwanie od rzeczywistości, wspomina J. Wa s i e w i c z, zob. op. cit., s. 77. Badacz podkreśla, że ratunek przed nicością u Jacobiego i Jean Paula to uznanie osobowego Boga (s. 79-80). 
ności, pozorności, uwikłań w maski, role, także te narzucone przez literaturę. Nietrudno zauważyć, że część z nich to strategie ironii romantycznej, która zbliża się do nihilizmu w przypadku takich autorów, jak Tieck czy Jean Paul.

W interesujących mnie tekstach rządzi gusdorofowska „noc negatywna”, saturniczna, noc odwróconych sensów czy sensów wydrążonych ${ }^{19}$. Szczególnego znaczenia nabiera pojęcie nicości, próżni oznaczającej albo absolutną zagładę, albo mękę pustej, martwej wieczności ${ }^{20}$. Jacobi wyznaje: „mam wstręt do nicości, tego, co absolutnie nieokreślone, co na wskroś puste [...]"21. Podobne reakcje mają wzbudzić obrazy nicości w utworach literackich. U Jean Paula to ,zdrętwiała, niema nicość”, ,wieczna burza, nad którą nie panuje nikt”, ,,pusty oczodół”, który Chrystus znajduje w miejscu Boskiego oka, „wydrążona w wiecznej nocy kopalnia" pochłaniająca gruzy kosmicznego gmachu ${ }^{22}$. Rozdrożny, bohater Straży nocnych, na końcu swej drogi odnajduje na cmentarzu nicość. Wielokrotnie powtarza, że ,Wszystko jest nicością i dławi samo siebie, i żarłocznie siebie połyka [...]"23. Według Geralda Gillespiego, to właśnie odwołania do nicości świadczą o nihilistycznym wymiarze powieści ${ }^{24}$. Podobne refleksje znaleźć można w Hyperionie Hölderlina czy w Lenzu Büchnera, utworach, których bohaterowie doświadczają tremendum wobec nicości, czy - jak mówi Hyperion „nieskończonej próżni” ${ }^{25}$. Dziecko z bajki Büchnera jest zawieszone w totalnej pustce. Nicością skażony jest także bezkresny step Marii, w którym wszystko się rozpada, zmierza ku śmierci, zanika:

\footnotetext{
Włóczy się wzrok w przestrzeni, lecz gdzie tylko zajdzie,

Ni ruchu nie napotka, ni spocząć nie znajdzie [...]

Myśl [...] chyba lot zwinąwszy, zanurzy się w ziemię:

Tam znajdzie zbroje dawne, co zardzałe leżą,

I koście, co nie wiedzieć do kogo należą;
}

19 Zob. M. Janion, M. Żmi grodzka,op. cit., s. 138.

${ }^{20}$ Zob. M. Żmigrodzk a, op. cit., s. 29.

${ }^{21}$ F. H. Jacobi, op. cit., s. 58.

22 Jean Paul, Mowa wypowiedziana przez umarłego Chrystusa ze szczytu kosmicznego gmachu o tym, że nie ma Boga, przeł. M. Żmigrodzka [w:] M. Janion, M. Żmigrodzka, op. cit., s. 129-130.

${ }^{23}$ B on awe ntura, op. cit, s. 82.

${ }^{24}$ Zob. G. Gille s pie, Bonaventura's Romantic Agony: Prevision of an Art of Existential Despair, „MLN” Oct. 1970, vol. 85, nr 5, s. 704. Badacz podkreśla także upadek wiary Bonawentury we wszystko, także w tytanizm (s. 712). K. Brzović natomiast kładzie nacisk na negację w powieści zinstytucjonalizowanego pojęcia moralności. Zob. K. B rzo vić, „Nachtwachen von Bonaventura”: A Critique of Order, „Monatshefte” Winter 1984, vol. 76, nr 4.

${ }^{25}$ Pod koniec I księgi Hyperiona bohater utożsamia się z tymi, którzy utracili obraz szczęścia na rzecz roztaczającej się wokół nieskończonej próżni. Zwraca się do nich: „,...] wy, na wskroś opętani przez Nicość, która nami rządzi, tak do głębi przekonani, że urodziliśmy się dla tej Nicości, że Nicość kochamy, wierzymy w nią i zapracowujemy się dla niej, by powoli przejść w Nicość [...]"; F. Hölderli n, Pod brzemieniem mego losu. Listy. Hyperion, przekł. A. Milska, W. Markowska, Warszawa 1982, s. 326. 
Tam znajdzie pełne ziarno w rodzajnym popiele

Lub robactwo rozległe w świeżym jeszcze ciele;

Ale po polach błądzi nie sparłszy się na nic -

Jak Rozpacz - bez przytułku - bez celu - bez granic ${ }^{26}$.

Marek Bieńczyk pisze o kreacji ad nihilum jako zasadzie konstrukcji tego poematu, o kreacji à rebours dokonującej nicościującego oczyszczenia ${ }^{27}$. Z kolei Włodzimierz Szturc nazywa Marię „powieścią rozsypaną w otchłani”, wskazuje też na znaczenie w poemacie transcendencji negatywnej, nakierowanej na nicość, w której upatruje źródeł nihilizmu romantycznego ${ }^{28}$. Niewątpliwie jest to świat bez podstaw; nic - to wszystko, na czym można się oprzeć. Skazaniec czekający na egzekucję w Maju myśli o: „nocy bez dna”, „nocy najgłębszej”, ,przepaści nieskończonej”, ,„pustym cieniu” bez kresu, „wieczności bez celu”. Mówi:

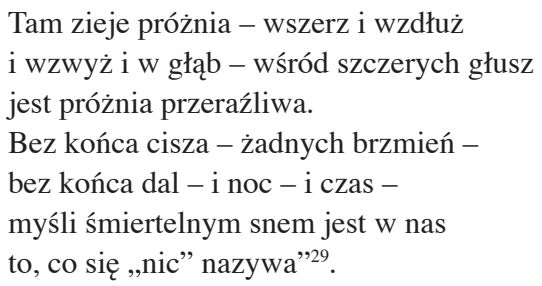

Wejście w śmierć to wejście w puste nic, ale wejście z pełną świadomością. Nicość rozumiana bywa dwojako - albo jako całkowity brak perspektywy wieczności, desubstancjalizacja, anihilacja, albo wręcz przeciwnie - jako wypełniająca wieczność, istotowo z nią zespolona. Nicość i otchłań to pojęcia w cytowanych tekstach często zestawiane, trudno oprzeć się wrażeniu, że romantyczna nicość bywa - paradoksalnie - substancjalna. To nic, które istnieje ${ }^{30}$.

${ }^{26}$ A. Malczewski, Marja: Powieść ukraińska, oprac. J. Ujejski, Kraków 1925, s. 14, podkr. - M.S. M. Maciejewski pisze o „ontycznej klaustrofobii” wyzwalającej się na ukraińskich stepach Marii; zob. M. Maci ejew s ki, „Spojrzenie w górę” i „,wokoło” (Norwid-Malczewski) [w:] Poetyka: gatunek - obraz. W kręgu poezji romantycznej, Wrocław 1977, s. 148.

${ }^{27}$ M. B ieńc zy k, „Wszystko w świecie tracić” ( $O$,Marii” Antoniego Malczewskiego) [w:] Oczy Dürera: o melancholii romantycznej, Warszawa 2002, s. 41.

${ }^{28}$ W. S zt u r c, op. cit., s. 168, 173, zob. też 164-165. Badacz pisze także o jedynym w Marii wyborze, jakim jest wybór między pustką (tam) a nicością (tu). Zob. też H. K ru k ow s k a, op. cit., s. 32-44 (badaczka pisze między innymi o zacieraniu śladów życia w Marii); M. Kalin ow s ka, Mowa i milczenie. Romantyczne antynomie samotności, Warszawa 1989, s. 67 (świat Marii określony jest jako „ufundowany na nicości”) oraz J. Ła w s ki, Marie romantyków. Metafizyczne wizje kobiecości: Mickiewicz - Malczewski - Krasiński, Białystok 2003, s. 498 (Maria nazwana jest tu „Księgą Genezis” pisaną na wspak, zmierzającą ku nieistnieniu). Odwołuję się tu tylko do niektórych, wybranych z ogromu ważnych interpretacji Marii.

${ }^{29}$ K. H. Mách a, Maj [w:] Maj. Wybór poezji, wyb. i przeł. J. Waczków, Warszawa 1971, s. 123.

${ }^{30}$ M. Żmigrodzka pisze o Strażach nocnych: „Bonawenturę prześladują dwie sprzeczne wizje koszmarnej nicości: śmierć jako synonim absolutnej zagłady i męka nieśmiertelności, samotnego 
Ważne miejsce w tekstach nicościowych zajmuje chaos, śmierć i rozkład, motywy wanitatywne wpisują się w proces anihilacji. W Strażach nocnych w proch rozsypuje się trup ojca bohatera, który z właściwą sobie ironią (czyniąc aluzję do filozofii idealistycznej) przemawia do cmentarnego robaka: „Iluż filozofom idealizm zredukowałeś do tego swojego realizmu?"31 Śmierć, zwłaszcza samobójcza, powraca niemal obsesyjnie w powieści Bonawentury. Według Ellis Finger, nihilizm tego utworu sprowadza się właśnie do odmowy życia ${ }^{32}$. W świecie Marii panuje niepodzielnie śmierć i rozkład, ziemia jest bezimiennym cmentarzem, sama Maria należy bardziej do śmierci niż do życia. Zapowiedź: „Zdobędziesz ty trumnę” towarzyszy Wacławowi od początku. Utwór otwiera nieuchronna prawda: „Bo na tym świecie śmierć wszystko zmiecie. I Robak się lęgnie i w bujnym kwiecie [...]"33. Cały tekst tylko ją potwierdza. Mocnym akordem zamykającym poemat jest martwe, bezwolne, nienaturalnie wygięte ciało Marii. Cmentarny robak z początku opowieści powraca na jej końcu: tulący się do łona bohaterki, jest - jak w Strażach nocnych - ostatecznym zwycięzcą. Trzeba podkreślić, że zaświaty Jean Paula nie są światem duchów, a światem umarłych - powstającym z trumien ciałom odpadają kolejno wszystkie członki, także i oni, jak u Bonawentury, rozsypują się w proch. Maj z kolei jest tekstem poświęconym przygotowaniom na śmierć, jest konfrontacją ze śmiercią. Nie bez powodu trupia czaszka, która pragnie na powrót zrosnąć się z kośćmi, przywrócić sobie jakikolwiek rodzaj bytu, choćby widmowego, pełni centralną rolę w Intermedium poematu. Oczywiście nie sama obecność śmierci świadczy o nihilistycznym wymiarze omawianych tekstów. Obrazy umierania, rozkładu mają nie tylko przypominać w nich o przemijaniu, odsyłać do czegokolwiek poza perspektywą ziemską, są - można powiedzieć - samozwrotne. Śmierć nie jest bowiem tak straszna, jak straszne jest niekończące się trwanie nicości. Każdy z bohaterów jest - jak w Jacobiego interpretacji Fichtego - zamkniętym w piekle własnej jaźni Ja. Jacobi pisze:

trwania w pustce martwej wieczności. W fantazmacie upiornego, samowystarczalnego, wszystko pożerającego Ja można znaleźć akcenty parodystycznej drwiny z fichteanizmu czy bystrą diagnozę moralnych dylematów indywidualizmu, które na dobre dręczyć będą romantyków dziewiętnastowiecznych" (op. cit., s. 29). J. Ławski natomiast pisze o romantycznym doświadczeniu otchłannościowym, związanym z nic istniejącym, substancjalnym, nadając temu zjawisku miano abyssyzmu; zob. Nicościq podszyty..., op. cit., s. 232.

${ }^{31}$ B onawentura, op. cit., s. 125.

${ }^{32}$ E. Finger, Bonaventura through Kreuzgang: Nachtwachen as Autobiography, „The German Quarterly" May 1980, vol. 53, nr 3, s. 292. Finger pisze o balansowaniu między nihilizmem a nadzieją w Strażach nocnych (s. 293). D. Skutnik odczytuje Straże nocne w kontekście filozofii Schellingiańskiej, szczególnie ujęcia chaosu-nicości; zob. Augusta Klingemanna „Straże nocne” nad człowieczeństwem [w:] Noc: symbol, temat, metafora, pod red. J. Ławskiego, K. Korotkicha, M. Bajki, t. I: Wokót „Straży nocnych” Bonawentury, Białystok 2011, s. 225-226. Uznaje powieść za dzieło nihilistyczne bardziej radykalne niż Mowa... Jean Paula (s. 228 i 235).

${ }^{33}$ A. Malczewski, op. cit., s. 45. 
Jeśli tym, co najwyższe, co mogę sobie przypomnieć i oglądać, jest moje puste i czyste, nagie i jedyne Ja, ze swoją samoistnością i wolnością - to rozważany ogląd siebie, owa rozumność jest dla mnie przekleństwem. - Przeklinam swoje istnienie ${ }^{34}$.

Rozdrożny śni o nieśmiertelności strasznej, bo pustej, w której nie ma nic prócz Ja pożerającego samo siebie w nieskończoność: „Żadnego przedmiotu wokół prócz wielkiego i straszliwego Ja, które pożerało samo siebie, a połykając znów siebie rodziło"35. Według Thomasa F. Barry’ego u Bonawentury odnaleźć można aluzje do Ja absolutnego, echa idealizmu Kanta i Fichtego - świadomość krążąca po morzu nicości prowadzi do szaleństwa ${ }^{36}$. Jean Paul w przedmowie do Clavisa pisze, że Fichteańskim bogiem jest ,absolutne Ja, samo siebie zjadające jak Erysichton, i samo siebie wskrzeszające jak Chrystus”, a ,absolutną mojość” nazywa „otchłannością otchłani” ${ }^{37}$. Bohater jego Mowy... mówi o „wieczności leżącej w chaosie i przeżuwającej samą siebie”. To nieustające przeżuwanie swojej nicości przypomina to, co Jacobi nazywa ruchem wahadłowym autorefleksji: człowiek by stać się swoim stwórcą, musi „,wedle swej istoty siebie zniszczyć, by zaistnieć jedynie w pojęciu, by siebie posiąść: w pojęciu czysto absolutnego wyjścia i wejścia, pierwotnie $-z$ niczego, $k u$ niczemu, dla niczego, $w$ nicość $[\ldots]^{\prime 38}$. Nicość oznacza samotność totalną, absolutną - dla umarłych Jean Paula i dla jego Chrystusa, a także - jeszcze wyraźniej - dla dziecka z bajki Büchnera, które płacze, bo nie ma na świecie nikogo, nie ma nawet samego świata. Utraciwszy ziemię pod stopami, ,zostało samiusieńkie i przysiadło, i zaczęło płakać. I siedzi tam aż dotąd, i jest samo, samiusieńkie" ${ }^{39}$. Podobne jest do niego - bardziej demoniczne - Pacholę Malczewskiego, rozpaczliwie samotni są wszyscy bohaterowie Marii $^{40}$. Protagonista Maja Vilem jest „więźniem tych czterech ścian”, wsłuchującym się w stopniowe umieranie własnych myśli, ich przechodzenie w koszmarną wieczność, która jest nicością. Także Hyperion Hölderlina zwierza

${ }^{34}$ F. H. Jaco bi, op. cit., s. 57.

${ }^{35}$ B o n aw en tu ra, op. cit., s. 113. Zdaniem M. Śliwińskiego Straże nocne to powieść godząca w racjonalizm europejski, Bonawentura wyprowadza bowiem wnioski z filozofii Kanta i Fichtego, występuje przeciw będącemu skutkiem racjonalizmu sekciarstwu, przeciw spekulatywności, dowodząc, że unicestwienie realności świata wynika z filozofii podmiotu; zob. Odrzucenie racjonalizmu w „Strażach nocnych” Augusta Klingemanna [w:] Noc: symbol, temat, metafora, op. cit., s. 263-267.

${ }^{36}$ T. F. B arry, Madness and the Disoriented Self in Bonaventura's „Nightwatches”, „The Journal of the Midwest Modern Language Association" Spring 1986, vol. 19, nr 1, s. 53.

${ }^{37}$ J. Pau 1, Clavis fichtiana seu leibgeberiana, przeł. P. Graczyk, „Kronos” 2011, nr 1, s. 68.

${ }^{38}$ F. H. Jac o bi, op. cit., s. 49. Na ten temat zob. J. Piórc z yń ski, op. cit., s. 40-41.

${ }^{39}$ G. Büchner, [Bajka babci], przeł. J. Liebert [w:] M. Janion, M. Żmigrodzka, op. cit., s. 145.

40 Absolutnej samotności bohaterów Marii poświęca część swojej książki M. Kalin o w s k a, op. cit., rozdz. „O samotności i milczeniu w Marii Malczewskiego”. W. Szturc pisze, że bohaterowie Marii skazani są na osobność, świat rozsypuje się w pył, w nicość, a o pesymizmie poematu decyduje brak nadziei; zob. op. cit., zwł. s. 166. 
się Bellarminowi z przerażającego doznania zamknięcia we własnym Ja: „,[...] jest mi czasem, jakbym czuł ducha świata, niczym ciepłą rękę przyjaciela, ale wnet budzę się z wrażeniem, jak gdybym trzymał swą własną dłoń" ${ }^{41}$.

Można, jak sądzę, mówić o dwóch drogach literackiej prezentacji takiego świata. Pierwsza ma charakter zbliżający się do strategii ironii romantycznej chodzi o chwyty burzenia iluzji widoczne także w wymiarze autoreferencjalnym dzieła, o ową grę wspomnianą przez Jean Paula. Świat przedstawiony jawi się tu wyłącznie jako wytwór jakiegoś Ja - narratora tekstu, świadomego burzyciela porządku i demaskatora (tu zwłaszcza Straże nocne i $O$ teatrze marionetek Kleista). W tym sensie ta droga zbliża się do Nietzscheańskiego nihilizmu aktywnego. Druga bliższa jest nihilizmowi pasywnemu, stwarza iluzję odwzorowania rzeczywistości już danej jako skażona rozpadem (Maria, Maj, bajka Büchnera, Mowa...). Obie drogi łączy to, że prymarną cechą świata przedstawionego jest zachwianie jego ontologicznego statusu, czemu służyć ma z ducha barokowy powracający w tekstach obraz świata jako teatru, jako snu lub jako wizji wariata ${ }^{42}$. Tymi właśnie trzema chwytami się teraz zajmę, pokazując, jak - tworząc szczególną ramę modalną - wpisują się one w kontekst romantycznego nihilizmu, desubstancjalizacji świata.

Jeśli chodzi o pierwszy z wymienionych chwytów - w tekstach nihilistycznych często nie jest to już wielki teatr świata, ale jego szczególna, jak gdyby pomniejszona, wersja - teatrzyk marionetek. Takie ujęcie obnaża przede wszystkim absurd życia, bezwolność i śmieszność człowieka poddanego nawet nie reżyserowi, ale samej roli, jaką przyszło mu odgrywać, roli, której jest niewolnikiem. U Bonawentury marionetki cierpią rzeczywiście, choć przecież są tylko budzącymi śmiech kukłami przywiązanymi do sznurków. Leszek Libera twierdzi, że apologia marionetki w Strażach nocnych obnaża śmieszność pragnień i iluzji, ale przede wszystkim jawi się jako rezultat kryzysu światopoglądowego wywołanego przez relatywizm Kanta ${ }^{43}$. Podobne jak u Bonawentury paradoksalne odwrócenie hierarchii pojawia się w dialogu Kleista $O$ teatrze marionetek. To nie człekopodobna lalka ma naśladować człowieka, ale odwrotnie. Antropocentryczny obraz świata zostaje zachwiany. Dla Kleista „przypadkowe wstrząśnięcia”, drgania sznurków mogą tworzyć iluzję celowości, co można odnieść do

${ }^{41}$ F. Hölderlin, op. cit., s. 294.

${ }^{42}$ Nawiasem mówiąc, przesunięcie z dominanty epistemologicznej na ontologiczną może przypominać wyznaczniki powieści postmodernistycznej; zob. B. Mc Hale, Powieść postmodernistyczna, przeł. M. Płaza, Kraków 2013.

${ }^{43}$ O marionetkach w Strażach nocnych pisze L. Libera, który dowodzi, że zawarta w powieści apologia marionetki obnaża śmieszność pragnień i iluzji, ale przede wszystkim stanowi rezultat kryzysu światopoglądowego wywołanego przez relatywizm Kanta; zob. op. cit., s. 218-222. Badacz pisze o znaczeniu Hanswursta (s. 220-221), a także o interesującym mnie eseju Kleista (s. 222). Według J. Wasiewicza marionetki w powieści wiążą się z odsłanianiem iluzji wolności, a moment empirycznej świadomości Fichtego staje się tu stanem permanentnym; zob. J. Wa si ewic z, op. cit., s. 90. 
pozbawionego harmonii, bezładnego, ale opartego właśnie na pozorach, życia człowieka. Jego „środek ciężkości”, który można rozumieć zarówno mechanicznie, jak duchowo - jest umiejscowiony w niewłaściwym miejscu. Najważniejsza dla Kleista jest jednak kwestia świadomości - lalka, która jej nie posiada, może tańczyć doskonale, bo reprezentuje schillerowską naiwność, wdzięk. Człowiek, uświadamiając sobie swój wdzięk, natychmiast go traci. Do poprzedniego stanu może powrócić, ale tylko dialektycznie - nie przez osłabienie refleksji, ale przez jej wzmocnienie. Doskonała może być tylko istota całkowicie nieświadoma jak marionetka, albo nadświadoma jak Bóg.

Jak wyjaśnić ten paradoks? Teatr marionetek obnaża skrywane mechanizmy. Dla Bonawentury nie ma możliwości dotarcia do autentycznego Ja, człowiek zawsze odgrywa jakąś rolę, nawet jeśli jest przekonany, że jej nie odgrywa, że jego rola jest prawdą. Jedyne, co można zrobić, to uświadomić sobie grę, w którą jest się wplątanym, co sprowadza się - jak w przypadku Rozdrożnego - do nieustannej demistyfikacji, zdzierania poszczególnych masek własnych i cudzych. Bohater Straży nocnych przyjmuje pozycję widza dostrzegającego grę we wszystkim, w całej powieści często padają porównania do sceny, każde wydarzenie wywołuje zainteresowanie właśnie jako przedstawienie i jest poddawane ocenie estetycznej (i etycznej zarazem). Życie określane jest jako spektakl i nazywane po wielekroć farsą i tragikomedią. Bóg jednak nie jest wielkim reżyserem tego świata - wybory ludzi są egoistyczne lub przypadkowe. Organizator spektaklu to zazwyczaj błazen, sam nie do końca panujący nad swymi aktorami, obsadzający role źle. Tak przedstawiony świat nie może mieć żadnej solidnej podstawy, nic dziwnego, że nicość jest punktem dojścia bohatera. Rozdrożny bywa sam takim błaznem - jest aktorem poruszającym marionetką Jasia Kiełbasy, ale w identyczny sposób inscenizuje sytuacje wśród ludzi, jak kiedy zapowiada koniec świata i „organizuje” Sąd Ostateczny. Staje się tym samym - jak pisze Gillespie - figurą Boga ${ }^{44}$. Marionetkowość jest również jakąś - zazwyczaj skazaną na porażkę - próbą wyjścia poza Ja, spojrzenia na siebie jak na kogoś innego, zdystansowania się, uzyskania szerszej perspektywy. Bohaterowie Straży nocnych (np. spotkany na cmentarzu niedoszły samobójca) opowiadają swoją własną historię jak cudzą (np. jako scenariusz przedstawienia kukiełkowego). Zapośredniczenie staje się wielopoziomowe, ta sama historia zyskuje kilka wariantów. Elementem takiej teatralizacji są także konstrukcje sobowtórowe, od których roi się w Strażach nocnych ${ }^{45}$. Inaczej teatralizacja dokonuje się w Marii - o tym aspekcie poematu badacze pisali wielokrotnie, różniąc się w jego interpretacji. Bieńczyk proponuje lekturę rozpoznającą „step jako cogito melancholijne, miejsce świadomości-po-stracie, która w Marii

${ }^{44}$ Zob. G. Gilles si e, op. cit., s. 714. Badacz pisze także o marionetkach u Kleista i Büchnera (s. 716-721).

${ }^{45} \mathrm{Na}$ temat powieści Bonawentury jako autobiografii, w której historie innych bohaterów stanowią warianty losów protagonisty zob. E. Fin ge r, op. cit., s. 283-298. 
organizuje theatrum dla ekspozycji siebie"46. Elżbieta Feliksiak natomiast odrzuca lekturę jednoznacznie melancholijną, Malczewskiego kreację świata jako teatru odnosi do koncepcji Calderonowskiej, dostrzegając w poemacie wymiar transcendentalny ${ }^{47}$. Lekturze nihilistycznej bliższa byłaby propozycja Bieńczyka, warto jednak zaznaczyć, że sama pokusa nicości nie musi wykluczać możliwości istnienia wyższego wymiaru, częściej stawia go po znakiem zapytania.

Teatralny rekwizyt, jakim są maski, pojawia się w tekstach romantycznych nie tylko jako symbol obłudy, ale na zasadzie Gombrowiczowskiej gęby. Oznaczają one role, od których nie sposób się uwolnić, albo od których uwolnić się można, tylko wpadając w inną rolę. To w tym sensie Rozdrożny przedstawia życie jako wir tańczących wokół niego masek:

I kręcą się maski w szybkim szalonym tańcu wokół mnie - wokół mnie, który nazywam się człowiekiem - a ja zataczam się w ich kręgu, od ich widoku kręci mi się w głowie i nadaremnie trudzę się, by pochwycić jedną z nich i zerwać maskę z prawdziwego oblicza; ale one tańczą, i tańczą - a ja - cóż mogę począć w tym kręgu ${ }^{48}$

Próby ściągania kolejnych masek przypominają opisany przez Jacobiego ciągły wysiłek podejmowany przez Ja, by wydobyć siebie samego z uwarunkowanego istnienia ${ }^{49}$. Najbardziej znaczący jest pod tym względem epizod powieści, w którym aktorka grająca Szekspirowską Ofelię utożsamia się z nią do tego stopnia, że poza rolą nie istnieje, nie może dotrzeć do swego Ja. Wyznaje:

Spójrz, nie mogę się wcale rozeznać, czy śnię - czy to gra tylko, czy prawda, i z kolei, czy prawda to coś więcej niż gra - jedna łuska przykrywa drugą, a ja często jestem bliska utraty rozumu [...]. Popatrz oto usiłuję doścignąć samą siebie, ale ja biegnę wciąż przed sobą a moje imię za mną i recytuję znów swoją rolę - ale rola nie jest mną ${ }^{50}$.

Według Rozdrożnego można jedynie uświadomić sobie tę grę, co sprowadza się do nieustającej demistyfikacji. Maski podważają możliwość jednoznacznej oceny rzeczywistości, wprowadzają niepokój. W Strażach nocnych maskę diabła nosi profanator zwłok wolnomyśliciela, co sprawia, że dla ludzi rzeczywiście staje się diabłem, jego dekapitacja nabiera wymiaru po części metafizycznego (choć

${ }^{46}$ M. B ieńczy k, op. cit., s. 40. J. Ławski natomiast pisze o „teatrze wiecznej Natury”, kreującym i unicestwiającym byty; zob. J. Ła w sk i, Marie..., op. cit., s. 498.

${ }^{47}$ Zob. E. Feliksiak, „Maria” Malczewskiego. Duch dawnej Polski w stepowym teatrze świata, Białystok 1997, rozdz. IV „Kto rozdał role na wielkiej scenie stepu?”, s. 101-134. Badaczka zmierza do ukazania teatralności Marii jako zacierania granicy między iluzją a rzeczywistością (s. 179). Za trop „teatru świata” uznaje także dynamikę zmagań między chaosem a ładem (s. 169).

${ }^{48}$ B o n a w e ntura, op. cit., s. 93. Według M. Turczyn maska w powieści staje się synonimem utraty siebie, zob. M. Tu rc zy n, W kręgu poetyki inności - „Straże nocne” Bonawentury. Zarys problematyki [w:] Noc: symbol, temat, metafora, op. cit., s. 173.

${ }^{49}$ Zob. F. H. Jac ob i, op. cit., s. 46.

${ }^{50}$ Bonawentura, op. cit., s. 111. 
nie ma tu przecież wyjścia poza rzeczywistość ziemską), po części - groteskowego. Rozdrożny poszukując własnego ja, chce uwolnić się od krążących wokół niego masek, ale uwolnić się nie może - kiedy próbuje, odnajduje na powrót nicość, którą egzorcyzmuje, przywołując na powrót maski: „Precz, jak najdalej od $J a$, tańczcie znów, o maski!" ${ }^{51}$ W Marii „obrzydłe maski” niezatrzymane w szalonym tańcu, demoniczne, podobnie jak w Strażach nocnych dokonują zbrodni, stają się tajemniczymi wykonawcami niezrozumiałego, a ciążącego nad całym światem przedstawionym poematu, wyroku śmierci. Także i tu maski „maskują próżnię świata”, karnawał jest pozorem życia, ale innego życia nie ma ${ }^{52}$. Ze Strażami nocnymi łączy je także - jak pisze Dorota Siwicka - szczególny rodzaj śmiechu, który jest reakcją na cierpienie ${ }^{53}$. I w tym przypadku odpowiedź na pytanie o prawdziwą tożsamość przebierańców jest niemożliwa:

\section{Maska twarz kryje - a kto się pyta O sprawy czyje, tego przywita Wrzawa, śmiech pusty ${ }^{54}$.}

Kulig przebierańców trwa „w nocy i we dnie”, nikt nie zważa na starego sługę oznajmującego, że to nie zapusty. Jest to podróż nieprzerwana, zamknięte, błędne koło. Jeśli, jak pisze Halina Krukowska, Maria jest poezją zmierzającą do odrzucenia masek i iluzji, zmierzającą do ogołocenia, ten proces deziluzji także - jak w Strażach nocnych - prowadzi do pustki ${ }^{55}$. Teatralny charakter ma również Intermezzo Maja - alegoryczna scena, w której występują przygotowujące się na śmierć Vilema: trupia czaszka, wiatr, szubienica, ptaki, elementy tworzące swoistą danse macabre, równie niepokojącą jak zapustowy korowód z Marii, choć tu - pozaludzką. W Maju, podobnie jak w Strażach nocnych, ostatnią maską Ja jest trupia czaszka. Można stwierdzić, że odwołanie się do metafory teatru w przywołanych tekstach podważa ontologiczny status przedstawionej rzeczywistości, przesuwa ludzką egzystencję w stronę fikcji, co prowadzi do sceptycyzmu poznawczego.

Równie daleko idące konsekwencje przynosi ujęcie świata jako wizji szaleńca i jako snu. Do tego porównania odwołał się sam Jacobi:

${ }^{51}$ Ibidem.

${ }^{52}$ M. Bieńczyk, op. cit., s. 48-49. Bieńczyk przywołuje tu słowa Starobinskiego o alegorii.

${ }^{53}$ Zob. D. Siwicka, Komizm upadku [w:] Noc: symbol, temat, metafora, op. cit., s. 185. Także A. Nawarecki wspomina o podobieństwach Straży nocnych z Mariq - tym razem przez motywy muzyczne; zob. A. N a w a re cki, „Dqć w róg przeraźliwie...” Dźwięki i słowa w „Strażach nocnych" [w:] Noc: symbol, temat, metafora, s. 206.

${ }_{54}$ A. Malczew ski, op. cit., s. 43.

${ }^{55}$ H. Krukowska pisze o ironicznej wrzaskliwości masek; zob. H. Kru k o w s k a, Noc romantyczna..., op. cit., s. 65. Dla E. Feliksiak karnawalizacja stanowi element teatralizacji świata Marii; zob. E. Fe lik siak, op. cit., rozdz. VII „Bez odwołania?”, a „Maski są częścią »stepowego teatru świata« rozpiętego między iluzją a realnością" (s. 217). 
Kiedy człowiek zostaje odcięty od rozumu, przejawiającego się w otaczającym go świecie zmysłowym i »przemożnie porządkującego« jego wyobraźnię, kiedy od »zmysłów « [Sinnen] przechodzi w sen, w »gorączkę« - staje się »obłąkany « [wahn-sinnig]: nie przeszkadza mu to, iż jego własny, zawsze będący dlań towarzyszem »czysty « rozum myśli o tym, co najbardziej niedorzeczne, przyjmuje te niedorzeczności i traktuje jako coś »pewnego « ${ }^{56}$.

Sen i szaleństwo przedstawia Jacobi jako pułapki odcięcia od rzeczywistości i od źródeł moralnych, od dobra i prawdziwości. Interesujące mnie tu teksty literackie rozbudowują obrazy takich oniryczno-obłąkańczych pułapek. W Strażach nocnych cały świat jest domem wariatów, w który - na wzór cebuli - wbudowane są mniejsze ${ }^{57}$. W szpitalu bohater spotyka obłąkanego uważającego się za Stwórcę. Świat ukazany jako dzieło wariata traci sens, traci wymiar teleologiczny, co więcej, narażony jest w każdym momencie na destrukcję. Warto przypomnieć, że takie usunięcie podstaw istnienia ma miejsce także w znanych ,szpitalnych” fragmentach Kordiana i Nie-Boskiej komedii, gdzie Apokalipsa dokonuje się tu i teraz, wśród wariatów uznających się za bogów. Rozdrożny porównuje wprost system szaleńca do systemu Fichtego, ironizując na temat filozofii tego ostatniego, która cały świat ,jak w ornat kieszonkowy wtłacza w niewielkie Ja"58. W Strażach nocnych obłąkany stwórca świata twierdzi, że człowiek oszalał, bo wyobraził sobie z powodu boskiej iskry, że sam jest Bogiem. Jest to niewątpliwie echo listu Jacobiego - konsekwencja przekonania, że zaprzeczenie istnienia Boga jest jednoznaczne z samoubóstwieniem Ja:

Człowiek może jednak dokonać takiego wyboru; owego jedynego wyboru: »nicość« albo »Bóg«. Wybierając nicość, sam czyni »siebie« Bogiem, tzn. czyni z Boga »widmo«; nie jest bowiem możliwe, kiedy nie ma Boga, aby to nie człowiek i wszystko, co go otacza, nie było samym $»$ widmem $\ll^{59}$.

W Marii i w Maju jest inne szaleństwo - rozpaczy. Najważniejszą część opowieści Vilema i Pacholęcia znamy wyłącznie z reakcji słuchaczy (strażnika i Wacława), którzy zostają - podobieństwo obu poematów jest tu zaskakujące - zarażeni ich mrokiem. Straszna realność nicości jest tu zamknięta w ramę szeptanej opowieści. Nie bez powodu pisze się o doświadczeniu agnostycznym w Marii, związanym zwłaszcza z postacią Pacholęcia ${ }^{60}$.

Także obraz świata jako snu odsyła do koncepcji Ja, jak u Jacobiego zamkniętego w sobie, pozbawionego podstaw. Filozof przeciwstawia rozum wyobraźni,

${ }^{56}$ F. H. Jac ob i, op. cit., s. 54.

${ }^{57}$ Aluzja do systemu Fichtego - zob. J. Ławski, przypisy do: B onawentura, op. cit., s. 142 .

${ }^{58}$ B onawentura, op. cit., s. 88.

${ }^{59}$ F. H. J acobi, op. cit., s. 62.

${ }^{60}$ W. S zt u rc, op. cit., s. 170. Postać Pacholęcia doczekała się wielu interpretacji. Zbiera je i szczegółowo omawia J. Brzozowski, O pacholęciu w „Marii” raz jeszcze [w:] Antoniemu Malczewskiemu w 170 rocznice pierwszej edycji „Marii”, red. H. Krukowska, Białystok 1997. 
a czuwanie snowi. W onirycznej rzeczywistości analizowanych tekstów nic nie jest pewne, zasady są ruchome, podobnie jak czas i przestrzeń, nie ma możliwości prawdziwej komunikacji. Porównanie życia do snu po raz kolejny każe myśleć o barokowych korzeniach, w romantycznych tekstach dominuje otchłan, która budzi trwogę. Ten nihilistyczny lęk wynika przede wszystkim stąd, że sen nie ma granic, że poza Ja nie ma świata, nie wiadomo czy sen się kończy i czy można wyjść poza jaźń.

Odwrócenie relacji sen-jawa ma w pewnym sensie miejsce także w Marii. Wacław w pieśni I poematu kołysany jest słodkim snem Nadziei, złe mary rozprasza poranek, ale już nad pieśnią II króluje śmiertelny sen Marii. Ten pierwszy zatem okazuje się złudą, a to, co nazwane było marą - spełnia się. W Strażach nocnych zamiennie jako maski lub sny określane są życiowe role. Cała powieść zaczyna się od podkreślenia przez Rozdrożnego jego odmienności - kiedy wszyscy pogrążeni są we śnie, on sam postrzega się jako jedynego ocalałego. Ta samoświadomość decyduje o jego wyjątkowości, która jednak może być iluzoryczna - zamyka go przecież w obrębie jego jaźni. W korespondencji z Ofelią, snami nazywa także odgrywanie ról (jak choćby miłosnej), które snami pozostają, nawet jeśli chce się uznać za rzeczywiste. W końcu protagonista sam śni dwa sny, które można odczytać jako odwrócenie snu jeanpaulowskiego: pierwszy - że jest nieśmiertelny, zamknięty w swoim Ja, które nie może się unicestwićc1 ${ }^{1}$ Z tego koszmaru budzi się z ulgą, pocieszając się realnością śmierci, jak bohater Richtera pocieszał się, że jest Bóg i nieśmiertelność. Drugi sen, w którym Rozdrożny widzi wstające trupy poszukujące Boga, to jeszcze jeden wariant Sądu Ostatecznego bez Sędziego. Takie samo podanie w wątpliwość istnienia porównanego do snu pojawia się w refleksji skazańca w Maju. Pytanie o status życia na ziemi i życia po śmierci jest pytaniem o sen:

Czy jest wszystko snem?
Czczym snem? - Czy sen ten jest bez śnienia?
Więc wszystko tutaj, żywot ten -
jest snem, i tylko w inny sen,
jutrzejszy, jutrznia ten sen zmienia ${ }^{62}$.

Zarzut nihilizmu postawiony przez Jacobiego miał zdemaskować racjonalistów jako ateistów ${ }^{63}$. Na pytanie o istnienie samoistnego rozumu, który jest pełnią dobra i prawdy, Jacobi opowiada aktem wiary. Bóg nie podlega unicestwieniu, bo nie daje się poznać pojęciowo. Jednocześnie Jacobi buduje obraz alternatywnej wersji rzeczywistości - takiej, w której Boga nie ma: „nie ma ni-

${ }^{61}$ J. Wasiewicz porównuje ten opis z doświadczeniem młodego Jacobiego i słowami Chrystusa Jean Paula, zob. J. Was i ewi c z, op. cit., s. 79.

${ }^{62}$ K. H. Mácha, op. cit., s. 122.

${ }^{63}$ Zob. J. P. Faye i M. Cohen-Halimi, op. cit., s. 45. 
gdzie dobra i prawdziwości; korzeń natury i wszelkich istot jest wtedy czystą nicością"64. Ten obraz świata, który nie objawia nic poza sobą zostaje odrzucony właśnie jako zbyt przerażający, nie do przyjęcia. Dla Hyperiona Hölderlina ,niebo wymarło, jest puste", takie przekonanie prowadzi go do rozpaczy, która musi zostać przezwyciężona ${ }^{65}$. W eseju $O$ nihilistach poetyckich Jean Paul pisze nie tylko o niebezpieczeństwach płynących z prymatu fantazji nad rzeczywistością, subiektywnego Ja nad tym, co zewnętrzne, ale także z usunięcia Boga z pola widzenia:,Tam, gdzie Bóg, niczym zachodzące słońce, znika za horyzontem, tam również świat po jakimś czasie wkracza w ciemność [...]"66. Mowę... można uznać za literackie wcielenie tych zagrożeń. Jean Paul pisze ją więc niejako wbrew sobie, ale właśnie dlatego swą wizję świata bez Boga, świata rozpadającego się, zamyka w ramę snu ${ }^{67}$.

Według Wasiewicza tekst Jean Paula prezentuje właśnie ten wymiar nihilizmu, który oznacza nieobecność, brak Boga ${ }^{68}$. Apokalipsa odbywa się nie w konkretnym czasie i miejscu, ale w świadomości. Śniący ma do niej dostęp tylko chwilowo, umarli zaczynają się rozpadać, dopiero usłyszawszy od Chrystusa, że nie mają Ojca. Ziemia, ludzie ze swoją wiarą w Boga, istnieją nadal. Bohater budzi się ze snu z radosnym, oczyszczającym poczuciem, że jego wizja była tylko snem. Jean Paul kazał się swemu bohaterowi od snu uwolnić i powrócić do istnienia opartego na boskich zasadach, Mme de Staël, tłumacząc tekst na francuski, to przebudzenie mu odebrała, co zaowocowało poetyckimi obrazami pustego nieba w poezji Alfreda de Vigny i Gérarda de Nerval, a następnie modernistów. Niepokój został jednak zasiany, nawet jeśli przeczytamy całość nieokaleczoną przez Mme de Staël. Protagonista budzi się bowiem po raz drugi - pierwsze przebudzenie ma miejsce w kosmicznym gmachu, we śnie. Jednak skoro to pierwsze nie było prawdziwe, nie ma pewności, że drugie jest ostateczne. Niepokojący motyw snu we śnie w romantyzmie pojawia się często: u Michaiła Lermontowa, Heinricha Heinego, Charlesa Nodiera, Nervala, Edgara Allana Poego.

Negacja czy anihilacja Boga w tekście literackim może przybierać rozmaite formy - niekoniecznie wizji śmierci Boga jak u Jean Paula, albo obłędu Boga jak u Bonaventury. Przestrzeń stepu w Marii jest przestrzenią raju po upadku. Oczywiście jest w Marii przeżycie religijne - dotyczy głównej bohaterki, ale jej „noc mistyczna” nie dominuje w poemacie. Bóg pozostaje daleki69. W Maju

${ }^{64}$ F. H. Jac ob i, op. cit., s. 55.

${ }^{65}$ F. Hölderlin, Pod brzemieniem mego losu. Listy. Hyperion, przeł. i oprac. A. Milska i W. Markowska, Warszawa 1982, s. 366. Zob. J. Wa s i e w i c z, op. cit., s. 69-77.

${ }^{66}$ Je a n Paul, Estetyka. Kurs przygotowawczy, op. cit., s. 62.

${ }^{67}$ Zob. M. Janion, M. Żmigrodzka,op. cit., s. 132-136.

${ }^{68}$ J. Wasiewicz, op. cit., s. 79.

${ }^{69}$ H. Krukowska pisze: „Mistyczne «daleko od ziemi» Marii odsłania, że Bóg «widzi» tylko biel. Reszta - w jego oczach jest ciemnością, nocą, niebytem”, H. Krukowska, Noc romantyczna..., op. cit., s. 54. O doświadczeniu religijnym Marii i wymiarze transcendentnym, który 
perspektywa zaświatów to - skontrastowana z bujną, tętniącą życiem przyrodą - perspektywa pustej, nieustającej nocy, gdzie ,żadnej - żadnej - żadnej skry, I tam tylko noc przebywa"70. Nie ma żadnego pocieszenia w Bogu. W Strażach nocnych najwyraźniejsza jest hipoteza, pojawiająca się również - choć jako odrzucona - u Jacobiego, że Bóg mógłby być przez człowieka wymyślony. Mógłby być także utożsamiony z nicością, skoro poeta-samobójca woła w pożegnalnym liście ,[... ] idę butnie ku tobie, Boże, czyli ku niczemu!'71

Ramy teatralna, oniryczna i obłąkańcza szczególnie sprzyjają romantycznemu wariantowi nihilizmu, podkreślając desubstancjalizację rzeczywistości, widmowość świata. Pozwalają wypowiedzieć to, co budzi trwogę. We wszystkich analizowanych tu tekstach łączą się z obrazami nicości. Teatr, sen i szaleństwo stają się w tym wypadku bronią obosieczną. $\mathrm{Z}$ jednej strony bowiem ujawniają chaos i iluzoryczność świata, demaskują bezwolność w nim człowieka, czyniąc go bardziej świadomym. $\mathrm{Z}$ drugiej strony stanowią pewne zabezpieczenie przed takim światem - jeśli to tylko fikcja: teatr, sen, mowa wariata, może da się jeszcze powrócić do optymistycznej wizji rzeczywistości?... Odwołanie się do takich chwytów zdradza owo rozdarcie romantycznych pisarzy skażonych nicością i nicość egzorcyzmujących.

\section{Magdalena Siwiec}

\section{MARIONETTES, MASKS AND DREAMS: ROMANTIC NOTHINGNESS}

Summary

This article examines the early Romantic discussions of 'nothingness', raised among others by August Klingemann, Jean Paul Richter, Georg Büchner, Heinrich von Kleist, Friedrich Hölderlin, Karel Hynek Mácha and Antoni Malczewski. At the heart of the debate, initiated by Friedrich Jacobi's critique of Fichte's philosophy of the ego, lies a concept of Romantic nihilism derived from the negation of transcendental idealism. The literary projections of the nihilist angst can be categorized as the theatrical, the oneiric and the insane. By mingling fascination and terror they effect the dissolution of reality.

jednak nie niweluje pesymizmu i tragizmu poematu, zob. G. Hal kie wi c z-S ojak, $C z y$ „Maria” jest poematem o złej nowinie? [w:] Antoniemu Malczewskiemu..., op. cit. O znaczenie Boskiego „wiecznego teraz", transcendencji w interpretacji Marii dopomina się E. Feliksiak; zob. E. Fe lik s i a k, op. cit., rozdz. III „Niebo nad stepem”, zwł. s. 81, 91.

${ }^{70}$ K. H. Mácha, op. cit., s. 123.

${ }^{71}$ B on awentura, op. cit., s. 80. M. Turczyn twierdzi, że zawarta w tym fragmencie alternatywa nie niweluje nihilistycznej tonacji utworu, ale podważa jej radykalizm, zob. M. Turc zy n, op. cit., s. 175. Najistotniejszy jest tu jednak kontekst listu Jacobiego do Fichtego. Jego wypowiedź dotyczącą istnienia Boga, który albo istnieje transcendentnie, albo jest tożsamy z Ja, P. Dehnel interpretuje następująco: „Tę alternatywę można sprowadzić do wyboru: nic albo Bóg”; P. De hne l, op. cit., s. 114. 